\title{
Free agency for CMAJ Editor-in-Chief
}

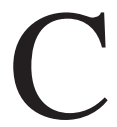

$M A J$ Editor-in-Chief Dr. Paul Hébert informed staff on Dec. 22,2010 , that he will not be returning to the helm of the journal once his current five-year contract expires Dec. 15, 2011.

"I will not be renewing a second term," Hébert told staff. "Not that I'm gone yet, but it's been a real honour and a privilege. I've just learnt so much."

"I've found it really rewarding, primarily because you guys are an outstanding team and I feel I've had a huge part in kind of getting you guys all together, at least in terms of hiring a bunch of you and getting the team together over the last four years. There's been no shortage of creative tension, either between myself and the CMA, or with some of the editors and the staff. But, you know, at the end, it's an amazing, amazing journal and it's all because of you guys. ... I'm really proud of all the work you've done."

Hébert later indicated in an interview that the rationale for his departure lay in a sense that he had accomplished the primary objectives he'd set out for the journal upon assuming the helm on Jan. 2 , 2007. "I promised to basically resuscitate the journal. I promised to put it on solid footing and basically raise its international stature amongst the research community and I've done that. And I feel that in the next phase of CMAJ's growth, it needs to develop some of its other pillars: the e-journal, the practice journal, other aspects of the journal and just basically, strengthen and consolidate some of these things I've already initiated. And that, I thought, would be best done under different leadership."

"In hiring an international team of respected editors, $C M A J$ now manages to attract practice-changing medical research from all around the world on a regular basis," Hébert added. "As a team, we have all raised the profile of $C M A J$ with health professionals, decision makers and the public alike. For our editorials, analysis and commentary, we speak with authority on a wide variety

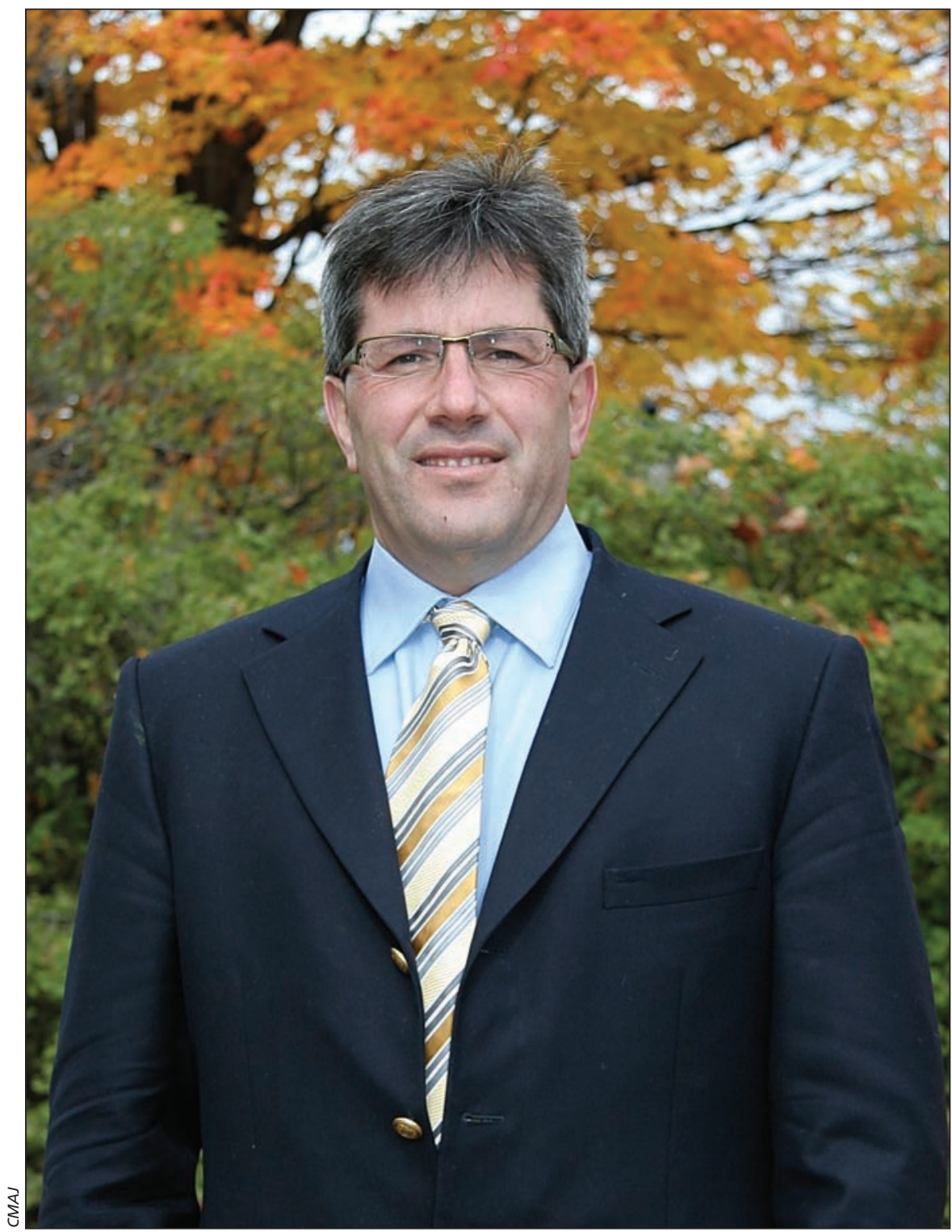

Dr. Paul Hébert was appointed CMAJ Editor-in-Chief on Jan. 2, 2007.

of issues, such as the long form census, warning labels on cigarette packages, and this past year, on the H1N1 epidemic. Many have had a significant impact as a consequence of widespread media attention and I'm really proud of our collective accomplishments and I'm now looking and setting my sights on new challenges."

CMA Secretary-General Paul-Émile Cloutier said in a statement that Hébert "has been an agent of change for the
$C M A J$, managing to revitalize it during a challenging time in journal publishing. In doing so, he and his team have further strengthened CMAJ's independent and trusted voice on clinical practice, as well as health policy and research."

"The steady growth in CMAJ's credibility over the last four years is a tribute to the leadership, creativity and commitment of Dr. Hébert and the entire CMAJ team," Cloutier added. 
Cloutier also indicated that the CMA's governing board will establish a search committee early in 2011 to select Hébert's successor.

Journal Oversight Committee Chairman Dr. Peter Tugwell credits Hébert with having "saved" the journal in the wake of the February 2006 dismissal of predecessor Dr. John Hoey. "The whole committee is incredibly proud of what he's done in terms of stabilizing it and setting out its reputation. It's in the top 10 general medical journals, with a very impressive impact factor. And it's also being increasingly useful for physicians across Canada, which is one of its mandates."
That said, Hébert's decision was not a surprise, Tugwell adds. "Being an editor is not easy. Quite a lot of editors only do one term. As much as I'd like to have seen more of him, by the end of his term, he'll have done what he needs to do."

Circumstances have changed, Tugwell explains. "Opportunities for dramatically doing new things may be a bit less now. Given the current fiscal climate, it perhaps doesn't surprise me as much as it would have. We're not seeing a lot of new funds around for major innovations."

While serving as CMAJ Editor-inChief, Hébert retained his status as professor of medicine, surgery, anesthesiol- ogy and epidemiology at the University of Ottawa and his hospital privileges at the Ottawa Hospital, working a rotation of one week every six weeks. During his tenure at the helm, Hébert also took an appointment as "strategic lead and advisor" to Canadian Institutes of Health Research President Dr. Alain Beaudet in the development of a national clinical research program. In December 2009, CMAJ's Journal Oversight Committee requested that he develop "a plan to complete his work at CIHR." Hébert left the CIHR position on June 30, 2010. Wayne Kondro, CMAJ

CMAJ 2011. DOI:10.1503/cmaj.109-3769 